\title{
A Guide to Different Intensities of Exercise, Vaccination, and Sports Nutrition in the Course of Preparing Elite Athletes for the Management of Upper Respiratory Infections during the COVID-19 Pandemic: A Narrative Review
}

\author{
Hamid Agha-Alinejad ${ }^{1}$, Amir Hossein Ahmadi Hekmatikar ${ }^{1}$, Ruheea Taskin Ruhee ${ }^{2}$ (D), \\ Mahdieh Molanouri Shamsi ${ }^{1}$ (D), Masoud Rahmati ${ }^{3}$ (D), Kayvan Khoramipour ${ }^{4,5, *(D)}$ and Katsuhiko Suzuki ${ }^{6, *(\mathbb{D})}$
}

1 Department of Physical Education and Sport Sciences, Faculty of Humanities, Tarbiat Modares University, Teheran 1411713116, Iran; halinejad@modares.ac.ir (H.A.-A.); a.ahmadihekmatik@modares.ac.ir (A.H.A.H.); molanouri@modares.ac.ir (M.M.S.)

2 Future Innovation Institute, Waseda University, Shinjuku 162-0041, Japan; ruhee@fuji.waseda.jp

3 Department of Physical Education and Sport Sciences, Faculty of Literature and Human Sciences, Lorestan University, Khoramabad 6816785468, Iran; rahmati.mas@lu.ac.ir

4 Institute of Neuropharmacology, Neuroscience Research Center, Department of Physiology and Pharmacology, Afzalipour School of Medicine, Kerman University of Medical Sciences, Kerman 7616914115, Iran

check for

updates

Citation: Agha-Alinejad, H.; Ahmadi Hekmatikar, A.H.; Ruhee, R.T.; Shamsi, M.M.; Rahmati, M.; Khoramipour, K.; Suzuki, K. A Guide to Different Intensities of Exercise,

Vaccination, and Sports Nutrition in the Course of Preparing Elite Athletes for the Management of Upper Respiratory Infections during the COVID-19 Pandemic: A

Narrative Review. Int. J. Environ. Res. Public Health 2022, 19, 1888. https:// doi.org/10.3390/ijerph19031888

Academic Editors: Filipe Manuel Clemente and Paul B. Tchounwou

Received: 7 December 2021

Accepted: 3 February 2022

Published: 8 February 2022

Publisher's Note: MDPI stays neutral with regard to jurisdictional claims in published maps and institutional affiliations.

Copyright: (C) 2022 by the authors. Licensee MDPI, Basel, Switzerland. This article is an open access article distributed under the terms and conditions of the Creative Commons Attribution (CC BY) license (https:// creativecommons.org/licenses/by/ $4.0 /)$.
5 Student Research Committee, Kerman University of Medical Sciences, Kerman 7619813159, Iran

6 Faculty of Sport Sciences, Waseda University, Tokorozawa 359-1192, Japan

* Correspondence: k.khoramipour@kmu.ac.ir or K.khoramipour@gmail.com (K.K.); katsu.suzu@waseda.jp (K.S.); Tel.: +98-9120356383 (K.K.); +81-4-2947-6898 (K.S.)

\begin{abstract}
Elite athletes use high-intensity training to maintain their fitness level. However, intense training can harm the immune system, making athletes suspectable to COVID-19 and negatively affecting their performance. In addition, the diet of athletes should be appreciated more as it is another influencer of the immune system, especially during the COVID 19 pandemic. The other important issue elite athletes face currently is vaccination and its possible intervention with their training. The present study attempts to discuss the impact of different training intensities, nutritional strategies, and vaccination on the immune system function in elite athletes. To this end, Scopus, ISC, PubMed, Web of Science, and Google Scholar databases were searched from 1988 to 2021 using the related keywords. The results of our review showed that although high-intensity exercise can suppress the immune system, elite athletes should not stop training in the time of infection but use low- and moderate-intensity training. Moderate-intensity exercise can improve immune function and maintain physical fitness. In addition, it is also better for athletes not to undertake high-intensity training at the time of vaccination, but instead perform moderate to low-intensity training. Furthermore, nutritional strategies can be employed to improve immune function during high-intensity training periods.
\end{abstract}

Keywords: athlete's immune system; training intensity; COVID-19; performance

\section{Introduction}

The immune system plays a significant role in protecting the human body from bacterial and viral infections and other environmental contaminants [1]. Several factors affect the function of the immune system, including age, gender, nutritional habits, medical status, exercise training, diet, and fitness level [2,3]. Both in its acute and chronic forms, physical exercise performance significantly alters the immune system function $[4,5]$. Current evidence suggests that regular exercise can exert both positive and negative effects on the normal functioning of the immune system [4,5]. It has been well documented that the modulation of the immune response by exercise depends on several factors, including regularity, intensity, duration, and type of exercise [6]. Accordingly, excessive, prolonged, 
high-intensity exercise may impair immune system function [7]. Notably, compared with non-elite athletes, higher training intensities are frequently employed by elite athletes to improve their physical fitness - as this training is needed for winning national and international medals - which may make them sensitive to infections [8]. Several studies indicate that upper respiratory tract infections (URTI) are common among elite athletes performing intense exercise $[9,10]$. URTI is an acute infection in the upper respiratory tract, including the nose, sinuses, and pharynx [11]. Athletes who perform strenuous exercise training are 2-6 times more likely to develop URTI if exposed to pathogens [12]. The risk of URTI increases among marathon runners between 1 and 2 weeks after the event due to reduced neutrophil function (Figure 1) [13]. Furthermore, a URTI association has been reported with COVID-19 [14]. These findings highlight the important issue that intense training and competition in elite athletes can suppress their immune system, predisposing them to COVID-19.

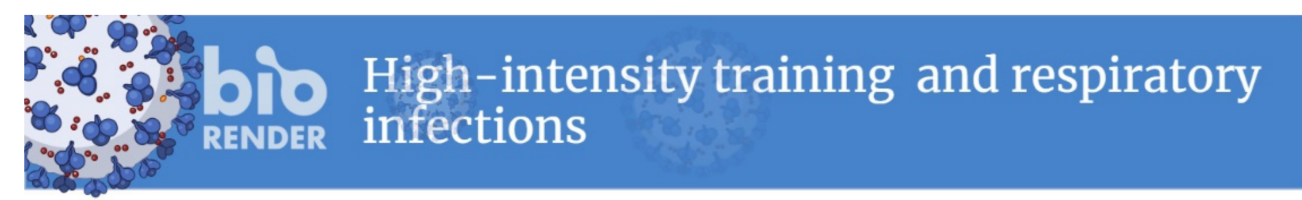

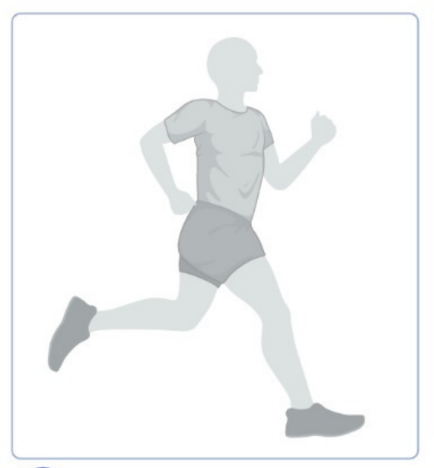

(1) High-intensity training

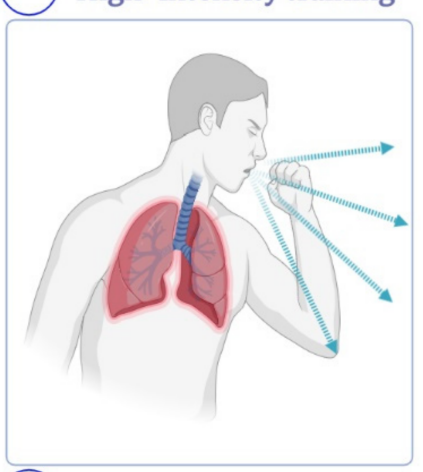

2

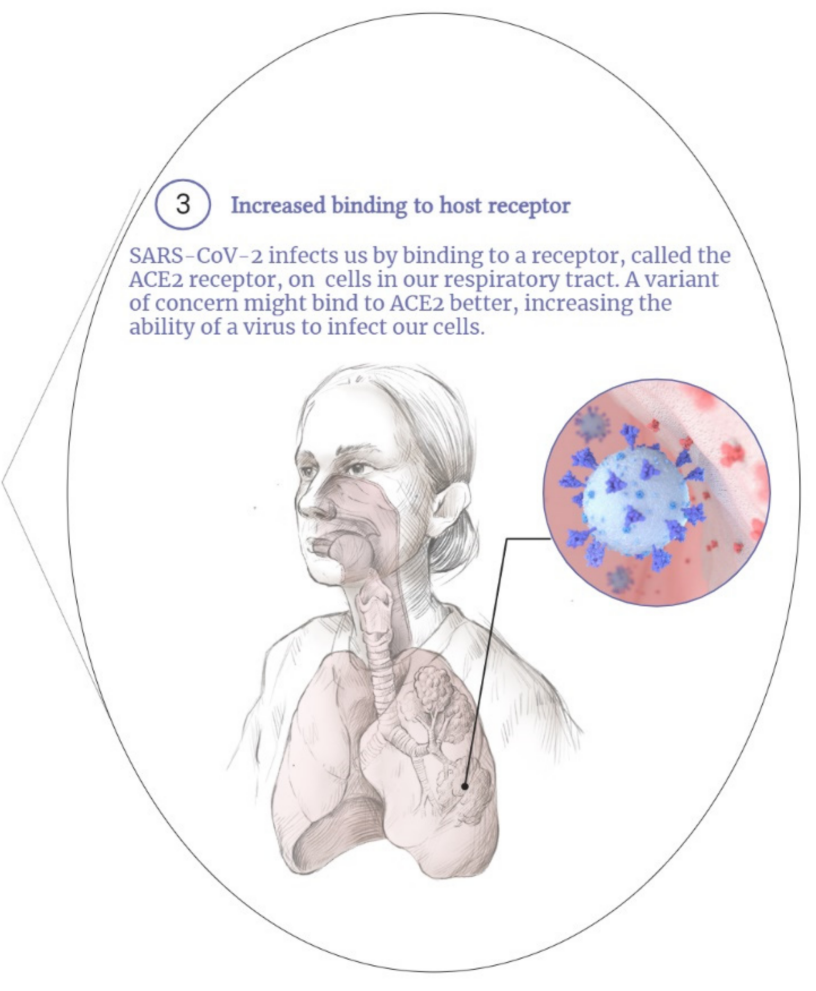

Figure 1. High-intensity exercise and upper respiratory tract infections.

The immune system plays a vital role in the success of elite athletes [15]. Immune depression in elite athletes taking part in strenuous sports can harm their performance [15]. In addition, due to the COVID-19 outbreak starting in 2020, the importance of the immune function should be particularly appreciated in athletes. Although sudden cessation of exercise can lead to a marked decline in immune function [8], in the case of impaired immunity and respiratory infections, exercise should not be stopped abruptly in elite athletes.

After undergoing home quarantine, many athletes have resumed intense training to maintain their physical fitness levels for upcoming competitions. However, studies have shown that after exercise cessation due to the COVID-19 pandemic, retraining should 
be started with caution [16]. Another big challenge that elite athletes face is resuming high-intensity training after being affected by the coronavirus. It has been shown that a high level of stress and anxiety during the infection may lead to athletes making wrong decisions about the best training intensity after returning to the athletic field [17]. As the sudden onset of intense exercise and training is associated with immunodepression [18], returning to sports activities and competition events should be supervised closely by their coaches and teams.

Nutrition is another critical factor influencing immunity because macro- and micronutrients are involved in multiple immune processes [19]. Nutritional deficiencies can compromise the immune system response and increase susceptibility to infections, including COVID-19, especially in elite athletes [20]. Therefore, elite athletes who want to perform high-intensity exercises during the COVID-19 pandemic should follow proper nutritional strategies. Additionally, elite athletes should receive vaccines to improve their immune system, thus helping them fight against COVID-19. One concern about elite athlete vaccination is continuing high-intensity training when they receive vaccine shots [21]. In the present study, an attempt is made to discuss the impact of different training intensities, nutritional strategies, and vaccination on the immune system function in elite athletes.

\section{Analysis Method}

\subsection{Search Strategy}

A literature search was conducted on Scopus, Web of Science, ISC, Pub-Med, and Google Scholar databases from 1988 to 2021 to find the related articles using several keywords, i.e., low-intensity exercise and immune system, moderate-intensity exercise and immune system, high-intensity exercise and immune system, low-intensity exercise and athlete recovery, moderate-intensity exercise and athlete recovery, high-intensity exercise and athlete recover, sports nutrition and athlete immune system, athlete stress and immune system, athlete sleep and immune system, carbohydrate and athlete immune system, vaccination and elite athletes.

\subsection{Inclusion and Exclusion Criteria}

In this review, we included any randomized single or double-blinded case-control, cohort, or experimental study with an intervention involving or an objective to explore the relationship between different intensities of exercise and immunity in athletes. Studies with unclear statements or results, not mentioning exercise intensity, and do not have a control group, were excluded. In addition, studies published in languages other than English were excluded.

\section{Results and Discussion}

\subsection{Low-Intensity Exercise and Athletes' Immune Systems}

There is very little research on low-intensity training and athletes' immune systems. Low-intensity training (e.g., below the first ventilatory threshold, at stable lactate concentrations $<2 \mathrm{mM}$ or with an intensity of less than $37-45 \% \mathrm{VO}_{2 \mathrm{max}}$ ), is also referred to as long slow distance training or zone-1 training. Steensberg et al. [22] reported increased IL-6 and IL-10 after $3 \mathrm{~h}$ and $26 \mathrm{~min}$ of low-intensity exercise. Mee-Inta et al. [23] concluded in their review study that low-intensity exercise can reduce inflammation. It has also been reported that low-intensity exercise (less than $60 \% \mathrm{VO}_{2 \max }$ ) for less than 60 min can reduce inflammation and improve immune function [24]. Tenorio et al. [25] examined the effect of low-versus high-intensity exercise training on inflammation and endothelial dysfunction biomarkers in adolescents with obesity in a 6-month randomized exercise intervention study. Interestingly, they found that high and low exercise intensities can improve immune function (neutrophils, monocytes, tumor necrosis factor-alpha).

Generally, low-intensity exercise has been considered to be a good strategy for elite athletes' recovery and reducing post-competition stress [26]. Taken together, these stud- 
ies indicate that low-intensity exercise can create a positive adaptation in the immune system (Table 1).

Table 1. A review of low-intensity exercise on the immune system.

\begin{tabular}{cccc}
\hline Authors & Intensity & Results & Source \\
\hline Mee-Inta et al. (2019) & Low & $\begin{array}{c}\text { Increases IL- 10 and IL-6 and decreases } \\
\text { cortisol levels }\end{array}$ & {$[23]$} \\
Tenorio et al. (2019) & Low & $\begin{array}{c}\text { Increases IL- 10 levels and T cell numbers. } \\
\text { Improves immune system function }\end{array}$ & {$[25]$} \\
$\begin{array}{c}\text { Petersen and Pedersen. } \\
\text { (2005) }\end{array}$ & Low & $\begin{array}{c}\text { Decreases IL- 1 } \beta \text { and TNF- } \alpha \text { levels. } \\
\text { Improved immune system function } \\
\text { Increase in IL- 10 and T cells. Improves } \\
\text { immune system function }\end{array}$ & [27] \\
\hline
\end{tabular}

\subsection{Moderate-Intensity Exercise and Athletes' Immune Systems}

Moderate-intensity exercise performed between first and second lactate or ventilatory threshold (i.e., zone-2) and causes accumulated lactate levels [28]. Performing exercise with an intensity of 45 to $65 \% \mathrm{VO}_{2 \max }$ is considered moderate-intensity exercise.

MacIntosh et al. [29] reported that regular moderate-intensity training can reduce inflammation, and increase IL-10 and T-cell function. Other studies showed that if moderateintensity exercise is performed for more than $60 \mathrm{~min}$, it can increase inflammation [30]; otherwise it decreases inflammation [26]. It has been reported that IL-10, an anti-inflammatory cytokine, increases in both intense and moderate-intensity exercise [31]. However, moderateintensity exercise has been shown to reduce cytokine storms and increase white blood cells, lymphocytes, and T cells [32].

In another study, Fashi et al. [33] concluded that four weeks of aerobic exercise reduced inflammation in the lung. Shiri et al. [34] examined the effect of six weeks of endurance training on tumor tissue IL-10 levels in breast cancer-bearing mice, and reported a significant increase in IL-10 levels.

Taken together, these studies demonstrate that moderate-intensity exercise is the best strategy in preventing suppression of the immune system (Table 2).

\subsection{High-Intensity Exercise and Athletes' Immune Systems}

High-intensity exercise refers to an intensity higher than $70 \%$ of $\mathrm{VO}_{2} \max$ [35]. Highintensity or "zone-3" training (e.g., $>4$ mmol lactate/L blood, $>90 \%$ maximal heart rate) involves intermittent intervals exercises (short, high-intensity sprints) [36]. Some markers of the immune function change within a few days after long-term intense endurance physical exercise. Neutrophils and NK cell functions, salivary immunoglobulins A (IgA), and some types of inflammatory macrophages are shown to undergo negative changes following this kind of exercise training [37]. In addition, based on the "open window" theory, 3 to $72 \mathrm{~h}$ after intense exercise an infectious agent may be able to invade the host body, thus increasing the risk of opportunistic infections [38] (Figure 2). 
Table 2. Effect of different intensities of exercise on immune system.

\begin{tabular}{|c|c|c|c|c|}
\hline Author & $\begin{array}{l}\text { Type of } \\
\text { Exercise }\end{array}$ & $\begin{array}{l}\text { Intensity of } \\
\text { Exercise }\end{array}$ & Results & Reference \\
\hline Raines et al. (2020) & Resistance & $45 \%, 75 \%$ and $95 \% 1 \mathrm{RM}$ & $\begin{array}{l}\text { Increase in IL- } 6 \text { at } 75 \% \text { and } \\
95 \% 1 \mathrm{RM} \text { No change in } 45 \% \\
1 \mathrm{RM}\end{array}$ & [39] \\
\hline Xiao et al. (2020) & Resistance and aerobic & $\begin{array}{l}\text { Walking: } 5 \text { days a week, } \\
30 \text { min with an average } \\
\text { intensity of } 45 \mathrm{VO}_{2} \text { max for } \\
12 \text { weeks. } \\
\text { Resistance training: } 2 \text { sets of } \\
\text { resistance training with } \\
\text { banding and Borg scale } \\
\text { between } 12 \text { to } 13 . \text { Intensity } \\
\text { was higher than } 60 \% 1 \mathrm{RM} \text {. }\end{array}$ & $\begin{array}{l}\text { High-intensity resistance } \\
\text { training: Increases IL-1 and } \\
\text { TNF- } \alpha \text { and C-reactive } \\
\text { protein.Walking: Increases } \\
\text { IL-10 }\end{array}$ & {$[40]$} \\
\hline $\begin{array}{l}\text { Scheffer and Latini } \\
\qquad(2020)\end{array}$ & High-intensity & Review study & $\begin{array}{l}\text { Exercise intensity } 46-63 \% \\
\mathrm{VO}_{2} \text { max: Increases } \\
\text { anti-inflammatory cytokines } \\
\text { including IL-10, IL-6, } \\
\text { and IL-7. } \\
64 \text { to } 100 \% \mathrm{VO}_{2} \text { max } \\
\text { increases L-1 } \beta, \text { IL-6, TNF- } \alpha \text {, } \\
\text { IL-17A and IL-15 }\end{array}$ & [41] \\
\hline Dixit (2020) & Aerobic & Review study & $\begin{array}{l}45 \text { to } 60 \% \mathrm{VO}_{2} \text { max increases } \\
\text { antipathogen activity, } \\
\text { recirculation of } \\
\text { immunoglobulins, } \\
\text { anti-inflammatory cytokines, } \\
\text { neutrophils, NK cells, } \\
\text { cytotoxic T cells, and } \\
\text { immature B cells. }\end{array}$ & [42] \\
\hline Highton et al. (2020) & Aerobic & $\begin{array}{c}20 \text { min walking at } 60-70 \% \\
\mathrm{VO}_{2} \text { peak }\end{array}$ & $\begin{array}{l}\text { Increase notrophil and } \\
\text { monocyte }\end{array}$ & [43] \\
\hline Sitlinger et al. (2020) & Moderate intensity & Review study & $\begin{array}{l}\text { Increases T cells, natural } \\
\text { killer cells, neutrophils, } \\
\text { monocytes, and B cells }\end{array}$ & [44] \\
\hline de Souza et al. (2018) & Aerobic & $\begin{array}{c}\text { Running on a treadmill at a } \\
\text { speed of } 3.0 \mathrm{~km} / \mathrm{h} \text { in } \\
\text { increments of } 1.0 \mathrm{~km} / \mathrm{h} \\
\text { every minute until voluntary } \\
\text { exhaustion } \\
\text { Running with moderate } \\
\text { intensity for } 20 \text { min at } \\
65-75 \% \text { of HRpeak }\end{array}$ & $\begin{array}{l}\text { Increases IL-6, IL-4, and } \\
\text { interferon- } \gamma \text {. } \\
\text { Decrease IL-6, IL-4, and } \\
\text { interferon- } \gamma \text {. }\end{array}$ & [45] \\
\hline Hajizadeh et al. (2018) & Aerobic & $\begin{array}{l}\text { Over the first } 12 \text { weeks of the } \\
\text { intervention, walked or } \\
\text { jogged on a treadmill at } \\
45-55 \% \text { of their } \mathrm{VO}_{2} \mathrm{max} \\
(25-30 \mathrm{~min} / \mathrm{day}, \\
3-4 \text { days / week), and after } \\
\text { that exercised by an intensity } \\
\text { of } 56-69 \% \text { of } \mathrm{VO}_{2} \mathrm{max} \\
\text { ( } 40-45 \text { min/day, } \\
4-6 \text { days / week) over the } \\
\text { final } 12 \text { weeks. }\end{array}$ & $\begin{array}{l}\text { Decrease IL-1 } \beta, \text { IL- } 6 \text {, IL-8, } \\
\text { TNF- } \alpha \text { and increase IL-10 }\end{array}$ & [46] \\
\hline
\end{tabular}


Table 2. Cont.

\begin{tabular}{|c|c|c|c|c|}
\hline Author & $\begin{array}{l}\text { Type of } \\
\text { Exercise }\end{array}$ & $\begin{array}{l}\text { Intensity of } \\
\text { Exercise }\end{array}$ & Results & Reference \\
\hline Durrer et al. (2017) & Aerobic & $\begin{array}{c}7 \times 1 \text { min at } \sim 85 \% \text { maximal } \\
\text { aerobic power output, } \\
\text { separated by } 1 \text { min of } \\
\text { recovery on a cycle } \\
\text { ergometer. }\end{array}$ & Increases TNF- $\alpha$ & [47] \\
\hline Szlezak et al. (2016) & Aerobic and anaerobic & Systematic review & $\begin{array}{l}\text { Exercise with an intensity of } \\
45 \text { to } 65 \% \mathrm{VO}_{2} \text { max: increases } \\
\mathrm{T} \text { cells, natural killer cells, } \\
\text { neutrophils, monocytes, and } \\
\text { B cells } \\
\text { Exercise with an intensity of } \\
64 \text { to } 100 \% \mathrm{VO}_{2} \text { max: } \\
\text { increases L- } 1 \beta \text {, IL-6, TNF- } \alpha \text {, } \\
\text { IL-17A and IL-15 }\end{array}$ & [48] \\
\hline Dorneles et al. (2016) & Aerobic and anaerobic & $\begin{array}{c}10 \times 60 \mathrm{~s}\left(85-90 \% \mathrm{P}_{\text {Max }}\right) / 75 \mathrm{~s} \\
\left(50 \% \mathrm{P}_{\text {Max }}\right) \\
10 \times 60 \mathrm{~s}\left(70-75 \% \mathrm{P}_{\text {Max }}\right) / 60 \mathrm{~s} \\
\left(50 \% \mathrm{P}_{\operatorname{Max}}\right)\end{array}$ & $\begin{array}{l}\text { increases IL-1ra, IL-6 and } \\
\text { IL-8. } \\
\text { increases IL-10 }\end{array}$ & [49] \\
\hline Sarir et al. (2015) & Anaerobic & $\begin{array}{l}\text { Running on a treadmill for } \\
\text { five days, } 10 \mathrm{~min} / \text { day at a } \\
10 \mathrm{~m} / \mathrm{min} \text { speed. Then, six } \\
\text { sessions per week at } 95-100 \% \\
\mathrm{VO}_{2} \mathrm{max} \text { for six weeks. } \\
\text { Active rest was performed } \\
\text { between intervals for } 60 \mathrm{~s} \text { at } \\
16 \mathrm{~m} / \mathrm{min} \text {. }\end{array}$ & increases IL- 6 and TNF- $\alpha$ & {$[50]$} \\
\hline Neves et al. (2015) & Anaerobic and aerobic & $\begin{array}{l}\text { High-intensity exercise }(80 \% \\
\mathrm{VO}_{2} \text { peak), } \\
\text { low exercise intensity ( } 40 \% \\
\mathrm{VO}_{2} \text { peak). }\end{array}$ & $\begin{array}{l}\text { High-intensity exercise: } \\
\text { increases in leukocyte, } \\
\text { Lymphocyte, and monocyte. } \\
\text { Low-intensity exercise: does } \\
\text { not produce any changes. }\end{array}$ & [51] \\
\hline Zwetsloot et al. (2014) & Anaerobic & $\begin{array}{c}\text { Two weeks of cycle } \\
\text { ergometer, } 3 \text { session per } \\
\text { week (8-12 intervals; } 60-\mathrm{s} \\
\text { intervals, } 75 \text {-s active rest) at } \\
100 \% \mathrm{VO}_{2} \text { max. } \\
\text { Moderate training ( } 20\end{array}$ & $\begin{array}{l}\text { Increases IL-6, IL-8, IL-10, } \\
\text { monocyte and TNF- } \alpha \text {. }\end{array}$ & [52] \\
\hline $\begin{array}{l}\text { Gholamnezhad et al. } \\
\text { (2014) }\end{array}$ & Anaerobic and aerobic & $\begin{array}{c}\mathrm{m} / \mathrm{min}, 30 \mathrm{~min} / \text { day, } 6 \text { days a } \\
\text { week, eight weeks), } \\
\text { overtraining ( } 25 \mathrm{~m} / \mathrm{min}, \\
60 \mathrm{~min} / \text { day, } 6 \text { days a week, } \\
11 \text { weeks). }\end{array}$ & $\begin{array}{c}\text { Increases IL-10 } \\
\text { Increases TNF } \alpha, \text { IL-6, } \\
\text { interferon- } \gamma \text {, and IL-4. }\end{array}$ & [53] \\
\hline Zimmer et al. (2014) & Aerobic & $\begin{array}{c}\text { Exercise with } 30 \mathrm{~min} \text { at } \\
\text { moderate intensity on a } \\
\text { bicycle ergometer. }\end{array}$ & $\begin{array}{l}\text { Increases NK-cells, IL-6, and } \\
\text { CD8 (+) T-lymphocytes }\end{array}$ & {$[54]$} \\
\hline
\end{tabular}




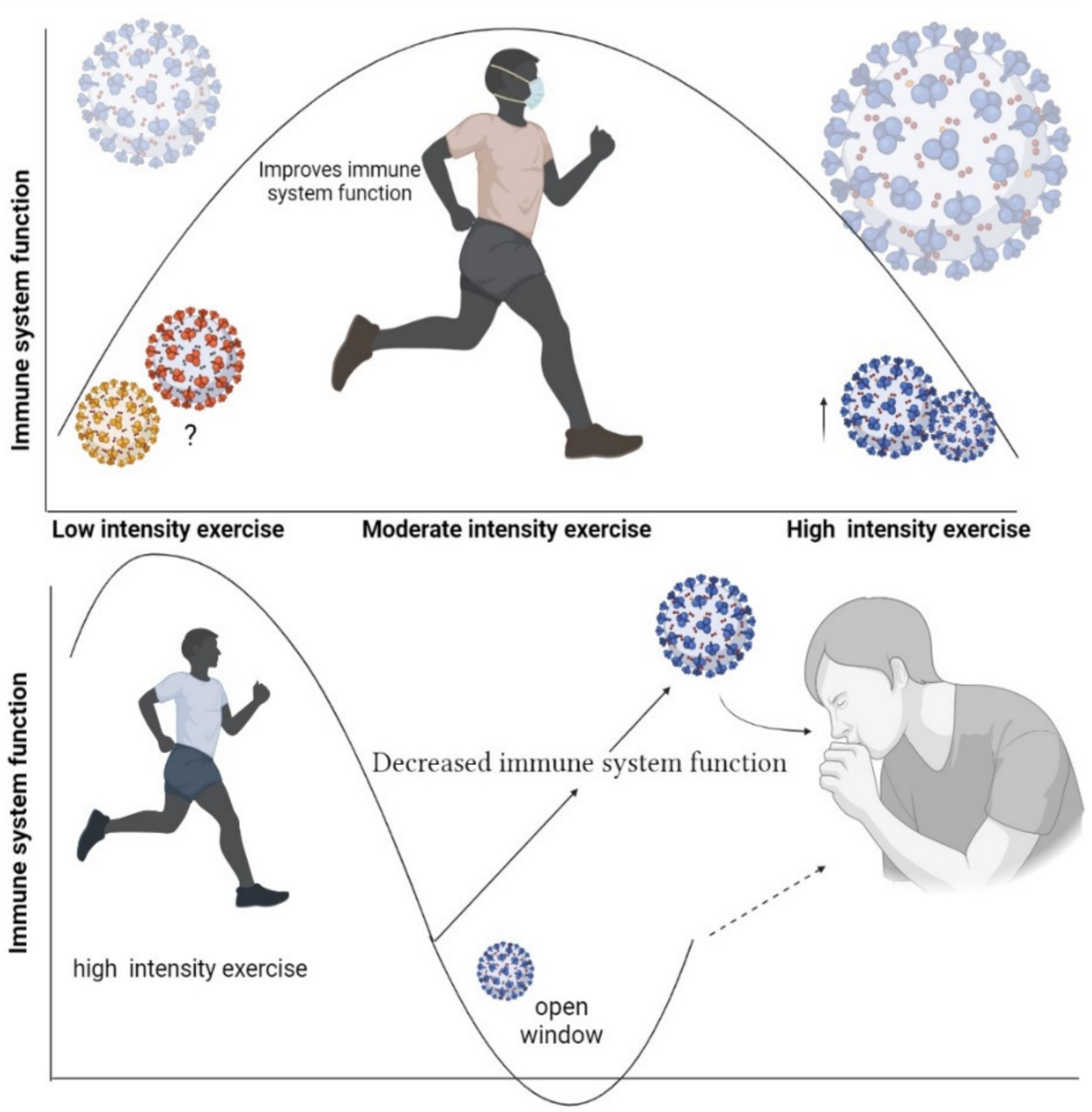

Figure 2. Open window theory after high-intensity training.

\section{Respiratory Infections and Exercise}

Evidence suggests that chronic exercise can increase upper respiratory tract infections in athletes [55]. The risk of athletes getting respiratory infections after intense exercise training is 7 times more than inactive individuals and 2 times more than active individuals [55]. Recurrent infections in athletes can be dangerous during a coronavirus pandemic [56].

Svenndsen et al. [57] reported that intense skiing increases the risk of infection by 3 times compared to recreational skiers. Nieman \& Wentz [58] reported that intense physical activity lasting less than $60 \mathrm{~min}$ can suppress the immune system. In line with these results, other studies have reported that intense exercise lasting more than 60 to 90 min can suppress immune function $[4,8]$. It has also been found that elite athletes who perform intense exercise to prepare for professional competitions may be more susceptible to infectious diseases [59]. Thus, elite athletes are more prone to URTI during preparation for a professional competition. Being overtired may make this situation worse. Mackinnon et al. [60] reported that after 4 weeks of high-intensity training in swimmers, 33\% of athletes showed symptoms of restlessness and $42 \%$ self-reported symptoms of URTI. During intense exercise, the activities of the lymphatic system are disrupted, which can negatively affect the immune system [61].

Allergic rhinitis is common among athletes due to regular high-intensity exercise [62]. To prepare for competitions, elite athletes undertake high-intensity training chronically trying to improve their physical fitness. It has been reported that, of 216 Olympic athletes, $56 \%$ had a history of conjunctivitis and rhinitis [62]. Allergic rhinitis impairs physical performance in professional athletes by affecting sleep, decreasing the ability to concentrate, or reducing physical fitness [62]. Continuous exposure to allergic rhinitis can increase the 
number of lymphocytes, eosinophils, neutrophils, basophils, and other leukocytes. This can cause the airways to overreact and eventually lead to fibrosis [63]. Allergens can also stimulate the airway epithelium to release IL-25, IL33, and thymic stromal lymphopoietin (TSLP). These cytokines can activate innate submucosal lymphocytes (ILC2) and release IL-4, IL-5, IL-9, and IL-13 [63], thereby causing airway wall remodeling, bronchial hyperresponsiveness, and goblet cell metaplasia [63]. These data, along with the open window theory, suggest that elite athletes are at high risk for COVID-19, highlighting the importance of vaccination and health care during infection.

\section{Management during Athletes Infection}

It has been found that viral infections can happen due to intense training in elite athletes, leading to a decrease in aerobic performance, especially among those affected by COVID-19 [64]. It has also been shown that athletes develop a fever during infection, and their muscle strength decreases [65]. The first step in managing athletes' infections is to reduce exercise intensity and use nutritional strategies [19]. Infection management in athletes can be divided into two categories: (a) strategies for severe infections, and (b) strategies for athletes with minor symptoms. Athletes who develop viral infections due to intense exercise and have a severe physiological condition must have active rest (i.e., low-intensity exercise) [66]. Protein catabolism increases in this situation [67]; thus, low-intensity resistance training and protein supplementation are the best choice [68]. For the second group, aerobic and moderate-intensity training can be appropriate. It is recommended that athletes do not stop exercising when they develop URTI or COVID-19 as it makes the situation worse because the sudden cessation of exercise due to illness can further weaken the immune system.

\section{How Can Athletes Get Vaccinated While They Continue Training?}

In the previous sections, the importance of vaccination in elite athletes was highlighted. One concern with athlete vaccination is that the first dose may have short-term side effects. These side effects vary depending on the type of vaccine [21]. It is recommended that athletes reduce exercise intensity when receiving the first dose of the vaccine [69]. Athletes performing moderate- to low-intensity exercise training do not need to reduce exercise intensity [69]. It has been found that nearly $94 \%$ of athletes experience arm pain, general fatigue, and fever after receiving the vaccine for 2 days [70]. Therefore, it can be suggested that, during this period, the intensity of training should be reduced in athletes who undertake high-intensity training. After the symptoms disappear, the intensity can gradually increase intensity. High-intensity training can continue until a day before the second dose, when training intensity should be reduced again. Elite athletes have been shown to experience headaches, chills, fever, and muscle aches for 1 to 3 days after receiving the second dose $[70,71]$. Thus, the exercise intensity should kept low until the fourth day after receiving the second dose and then increase gradually [21,72].

\section{The Importance of Nutrition}

Adherence to diets and dietary supplements during high-intensity interval training can minimize the suppression of the immune system [73].

It has been shown that carbohydrate consumption may improve immune function (Table 3), further improving sports performance [74]. Carbohydrates can increase performance by increasing blood glucose, and glucose can decrease cortisol and increase IL-10 levels [75], leading to improved immune response [75]. It is recommended that athletes use 30-70 $\mathrm{g}$ of carbohydrates per hour depending on the intensity and duration of exercise [76]. Additional recommendations to help immune function in athletes include (a) avoiding sudden dietary changes, (b) receiving 50\% of total daily calories from carbohydrate, and (c) consuming vitamin C and D [49]. In agreement with this, Gunde [73] stated that, for sports competitions that last more than $90 \mathrm{~min}$, the recommended dose is between 30 and $60 \mathrm{~g}$ per hour. It is clear that, with increasing the duration of sports competitions, the amount of 
carbohydrate intake should increase. For instance, Jagger et al. [77] stated that between 60 and $90 \mathrm{~g}$ of carbohydrate per hour should be consumed for competitions lasting more than $2.5 \mathrm{~h}$.

Table 3. The importance of nutrition for the immune function.

\begin{tabular}{ccc}
\hline Name of the Nutrient/Food & Impact on the Immune System & Source \\
\hline Blueberry & Reduces inflammation and oxidative stress & {$[78]$} \\
\hline Vitamin E & $\begin{array}{c}\text { Strengthen the immune system and } \\
\text { antioxidative activity }\end{array}$ & {$[79]$} \\
Papaya & $\begin{array}{c}\text { Strengthen the immune system due to its } \\
\text { enzymes (Papain), lycopene, carotenoids, } \\
\text { alkaloids, monoterpenoids, flavonoids, minerals, } \\
\text { and vitamins }\end{array}$ & {$[80]$} \\
\hline Yogurt & Immune system stimulating effects & {$[81]$} \\
\hline Ginger & Strengthen the immune system & {$[82]$} \\
\hline Green tea & Antioxidant/improves the immune system & {$[83]$} \\
\hline Vitamin D & $\begin{array}{c}\text { Regulation of immune system function and } \\
\text { proliferation of hematopoietic cells }\end{array}$ & {$[84]$} \\
\hline Zinc & $\begin{array}{c}\text { Improves the immune system and is effective for } \\
\text { upper respiratory infections }\end{array}$ & {$[85,86]$} \\
\hline
\end{tabular}

In addition to carbohydrates as the primary fuel for athletes, protein is needed to maintain/increase their muscle mass. The amount of protein an athlete needs depends on their type of activity. The general recommendation is an average intake of 1.3 to $1.8 \mathrm{~g}$ per $\mathrm{kg}$ per day [87]. A protein-rich diet is consumed to increase muscle mass, hypertrophy, strength, and fat loss, and improve recovery and performance. However, both positive and negative results have been obtained due to chronic protein supplementation or a proteinrich diet intake. Data from a systematic review and meta-analysis showed that protein supplementation during resistance exercise training does not improve muscle strength, size, or functional ability [88].

Herbal supplements or complementary and alternative medicines are familiar due to their unique medicinal properties. They also help to enhance the immune system by adding isolated vitamins and minerals. A wide range of phytonutrients, such as polyphenols, flavonoids, carotenoids, sulforaphane, curcumin, sulfides, and plant sterols, are found in herbs [76]. Some of these phytonutrients show protective effects against exercise-induced endotoxemia, and reduce exercise-induced inflammation and oxidative stress by stimulating the activity of protective enzymes such as phase 2 detoxification enzymes and antioxidative enzymes [89,90].

\section{Conclusions}

The results of our review showed that although high-intensity exercise can suppress the immune system, elite athletes should not stop training during the period of infection, but use low- and moderate-intensity training. Moderate-intensity exercise can improve immune function and maintain physical fitness. In addition, it is also better for athletes not to perform high-intensity training at the time of vaccination but instead perform moderateto low-intensity training. Furthermore, nutritional strategies can be employed to improve immune function during high-intensity training periods.

Author Contributions: H.A.-A., A.H.A.H. and M.R. conceived the review and drafted the manuscript. M.M.S., K.K., R.T.R. and K.S. made some additions to the text, revised the manuscript, and approved the final version. All authors have read and agreed to the published version of the manuscript.

Funding: This research received no external funding. 


\section{Institutional Review Board Statement: Not applicable.}

Informed Consent Statement: Not applicable.

Conflicts of Interest: The authors declare that the research was conducted without any commercial or financial relationships that could be construed as a potential conflict of interest.

\section{References}

1. Yazdanpanah, F.; Hamblin, M.R.; Rezaei, N. The immune system and COVID-19: Friend or foe? Life Sci. 2020, 256, 117900. [CrossRef]

2. Brolinson, P.G.; Elliott, D. Exercise and the immune system. Clin. Sports Med. 2007, 26, 311-319. [CrossRef] [PubMed]

3. Brodin, P.; Davis, M.M. Human immune system variation. Nat. Rev. Immunol. 2017, 17, 21-29. [CrossRef] [PubMed]

4. Khoramipour, K.; Basereh, A.; Hekmatikar, A.A.; Castell, L.; Ruhee, R.T.; Suzuki, K. Physical activity and nutrition guidelines to help with the fight against COVID-19. J. Sports Sci. 2021, 39, 101-107. [CrossRef]

5. Antrobus, M.; Cuttell, S.; Machado, L.R. Epigenetics, Exercise, and the Immune System. In Epigenetics of Exercise and Sports; Elsevier: Amsterdam, The Netherlands, 2021; pp. 183-199.

6. Pedersen, B.K.; Hoffman-Goetz, L. Exercise and the immune system: Regulation, integration, and adaptation. Physiol. Rev. 2000, 80, 1055-1081. [CrossRef] [PubMed]

7. Simpson, R.J.; Campbell, J.P.; Gleeson, M.; Krüger, K.; Nieman, D.C.; Pyne, D.B.; Turner, J.E.; Walsh, N.P. Can exercise affect immune function to increase susceptibility to infection? Exerc. Immunol. Rev. 2020, 26, 8-22. [PubMed]

8. Hekmatikar, A.; Shalamzari, S.; Shamsi, M. Hygiene protocols during the coronavirus pandemic for athletes: Biref report. Tehran Univ. Med. J. 2021, 79, 314-318.

9. Cicchella, A.; Stefanelli, C.; Massaro, M. Upper Respiratory Tract Infections in Sport and the Immune System Response. A Review. Biology 2021, 10, 362. [CrossRef]

10. Nieman, D.C. Risk of upper respiratory tract infection in athletes: An epidemiologic and immunologic perspective. J. Athl. Train. 1997, 32, 344 .

11. Miko, B.A.; Pereira, M.R.; Safdar, A. Respiratory tract infections: Sinusitis, bronchitis, and pneumonia. Princ. Pract. Transpl. Infect. Dis. 2019, 339-349.

12. Ronsen, O. Prevention and management of respiratory tract infections in athletes. New Stud. Athl. 2005, 20,49.

13. Akerstrom, T.C.; Pedersen, B.K. Strategies to enhance immune function for marathon runners: What can be done? Sports Med. 2007, 37, 416-420. [PubMed]

14. Mawaddah, A.; Genden, H.S.; Lum, S.G.; Marina, M.B. Upper respiratory tract sampling in COVID-19. Malays. J. Pathol. 2020, 42, 23-35. [PubMed]

15. Gleeson, M. Immune function in sport and exercise. J. Appl. Physiol. 2007, 103, 693-699. [CrossRef] [PubMed]

16. Haan, R.; Ali Alblooshi, M.E.; Syed, D.H.; Dougman, K.K.; Al Tunaiji, H.; Campos, L.A.; Baltatu, O.C. Health and Well-Being of Athletes During the Coronavirus Pandemic: A Scoping Review. Front. Public Health 2021, 9, 255. [CrossRef]

17. Muriel, X.; Courel-Ibáñez, J.; Cerezuela-Espejo, V.; Pallarés, J.G. Training load and performance impairments in professional cyclists during COVID-19 lockdown. Int. J. Sports Physiol. Perform. 2020, 16, 735-738. [CrossRef]

18. Gleeson, M.; Williams, C. Intense Exercise Training and Immune Function. In Limits of Human Endurance; Karger Publishers: Basel, Switzerland, 2013; Volume 76, pp. 39-50.

19. Gleeson, M.; Nieman, D.C.; Pedersen, B.K. Exercise, nutrition and immune function. J. Sports Sci. 2004, 22, 115-125. [CrossRef]

20. Calder, P.C. Nutrition, immunity and COVID-19. BMJ Nutr. Prev. Health 2020, 3, 74. [CrossRef]

21. Hull, J.H.; Schwellnus, M.P.; Pyne, D.B.; Shah, A. COVID-19 vaccination in athletes: Ready, set, go ... . Lancet Respir. Med. 2021, 9 , 455-456. [CrossRef]

22. Steensberg, A.; Fischer, C.P.; Keller, C.; Møller, K.; Pedersen, B.K. IL-6 enhances plasma IL-1ra, IL-10, and cortisol in humans. Am. J. Physiol. Endocrinol. Metab. 2003, 285, E433-E437. [CrossRef]

23. Mee-Inta, O.; Zhao, Z.-W.; Kuo, Y.-M. Physical Exercise Inhibits Inflammation and Microglial Activation. Cells 2019,8 , 691. [CrossRef] [PubMed]

24. Rose, G.L.; Skinner, T.L.; Mielke, G.I.; Schaumberg, M.A. The effect of exercise intensity on chronic inflammation: A systematic review and meta-analysis. J. Sci. Med. Sport 2021, 24, 345-351. [CrossRef] [PubMed]

25. Tenório, T.R.S.; Balagopal, P.B.; Andersen, L.B.; Ritti-Dias, R.M.; Hill, J.O.; Lofrano-Prado, M.C.; Prado, W.L. Effect of Low- Versus High-Intensity Exercise Training on Biomarkers of Inflammation and Endothelial Dysfunction in Adolescents with Obesity: A 6-Month Randomized Exercise Intervention Study. Pediatr. Exerc. Sci. 2018, 30, 96-105. [CrossRef]

26. Stöggl, T.L.; Sperlich, B. Editorial: Training Intensity, Volume and Recovery Distribution Among Elite and Recreational Endurance Athletes. Front. Physiol. 2019, 10, 10. [CrossRef] [PubMed]

27. Petersen, A.M.; Pedersen, B.K. The anti-inflammatory effect of exercise. J. Appl. Physiol. 2005, 98, 1154-1162. [CrossRef]

28. Goodwin, M.L.; Harris, J.E.; Hernández, A.; Gladden, L.B. Blood lactate measurements and analysis during exercise: A guide for clinicians. J. Diabetes Sci. Technol. 2007, 1, 558-569. [CrossRef]

29. MacIntosh, B.R.; Murias, J.M.; Keir, D.A.; Weir, J.M. What Is Moderate to Vigorous Exercise Intensity? Front. Physiol. 2021, 12, 682233. [CrossRef] 
30. Cerqueira, É.; Marinho, D.A.; Neiva, H.P.; Lourenço, O. Inflammatory Effects of High and Moderate Intensity Exercise-A Systematic Review. Front. Physiol. 2019, 10, 1550. [CrossRef]

31. Suzuki, K.; Nakaji, S.; Yamada, M.; Totsuka, M.; Sato, K.; Sugawara, K. Systemic inflammatory response to exhaustive exercise. Cytokine kinetics. Exerc. Immunol. Rev. 2002, 8, 6-48.

32. Suzuki, K.; Hayashida, H. Effect of exercise intensity on cell-mediated immunity. Sports 2021, 9, 8. [CrossRef]

33. Fashi, M.; Agha-Alinejad, H.; Asilian Mahabadi, H.; Rezaee Seraji, B.; Pak Rad, B. The Effect of Aerobic Exercise in Carbon Black Particulates Air Pollution on TLR4 and TNF- $\alpha$ Gene Expression in Lung Tissue of Male Rats. J. Sport Biosci. 2015, 7, 605-618. [CrossRef]

34. Shiri, Y.; Agha-Alinejad, H.; Gharakhanlou, R.; Amani Shalamzari, S.; Saei, M.A. Effect of six weeks endurance training on tumor tissue IL-10 cytokine levels in breast cancer bearing mice. Iran. J. Endocrinol. Metab. 2014, 16, 205-210.

35. Laursen, P.B.; Jenkins, D.G. The scientific basis for high-intensity interval training. Sports Med. 2002, 32, 53-73. [CrossRef]

36. Esteve-Lanao, J.; Foster, C.; Seiler, S.; Lucia, A. Impact of training intensity distribution on performance in endurance athletes. J. Strength Cond. Res. 2007, 21, 943-949. [CrossRef]

37. Campbell, J.P.; Turner, J.E. Debunking the Myth of Exercise-Induced Immune Suppression: Redefining the Impact of Exercise on Immunological Health Across the Lifespan. Front. Immunol. 2018, 9, 648. [CrossRef]

38. Pedersen, B.K.; Bruunsgaard, H. How physical exercise influences the establishment of infections. Sports Med. 1995, 19, 393-400. [CrossRef] [PubMed]

39. Raines, C.; Frosig, T.; Escobar, K.A.; Cotter, J.A.; Schick, E.E. Acute Resistance Exercise at Varying Volume Loads Does Not Enhance Plasma Interleukin-6. Int. J. Kinesiol. Sports Sci. 2020, 8, 37-42. [CrossRef]

40. Xiao, C.; Beitler, J.J.; Higgins, K.A.; Chico, C.E.; Withycombe, J.S.; Zhu, Y.; Zhao, H.; Lin, I.-H.; Li, F.; Jeon, S.; et al. Pilot study of combined aerobic and resistance exercise on fatigue for patients with head and neck cancer: Inflammatory and epigenetic changes. Brain Behav. Immun. 2020, 88, 184-192. [CrossRef] [PubMed]

41. Scheffer, D.D.L.; Latini, A. Exercise-induced immune system response: Anti-inflammatory status on peripheral and central organs. Biochim. Biophys. Acta (BBA) Mol. Basis Dis. 2020, 1866, 165823. [CrossRef] [PubMed]

42. Dixit, S. Can moderate intensity aerobic exercise be an effective and valuable therapy in preventing and controlling the pandemic of COVID-19? Med. Hypotheses 2020, 143, 109854. [CrossRef]

43. Highton, P.J.; White, A.E.M.; Nixon, D.G.D.; Wilkinson, T.J.; Neale, J.; Martin, N.; Bishop, N.C.; Smith, A.C. Influence of acute moderate- to high-intensity aerobic exercise on markers of immune function and microparticles in renal transplant recipients. Am. J. Physiol. Ren. Physiol. 2020, 318, F76-F85. [CrossRef] [PubMed]

44. Sitlinger, A.; Brander, D.M.; Bartlett, D.B. Impact of exercise on the immune system and outcomes in hematologic malignancies. Blood Adv. 2020, 4, 1801-1811. [CrossRef]

45. de Souza, D.C.; Matos, V.A.F.; dos Santos, V.O.A.; Medeiros, I.F.; Marinho, C.S.R.; Nascimento, P.R.P.; Dorneles, G.P.; Peres, A.; Müller, C.H.; Krause, M.; et al. Effects of High-Intensity Interval and Moderate-Intensity Continuous Exercise on Inflammatory, Leptin, IgA, and Lipid Peroxidation Responses in Obese Males. Front. Physiol. 2018, 9, 567. [CrossRef]

46. Hajizadeh Maleki, B.; Tartibian, B.; Mooren, F.C.; FitzGerald, L.Z.; Krüger, K.; Chehrazi, M.; Malandish, A. Low-to-moderate intensity aerobic exercise training modulates irritable bowel syndrome through antioxidative and inflammatory mechanisms in women: Results of a randomized controlled trial. Cytokine 2018, 102, 18-25. [CrossRef] [PubMed]

47. Durrer, C.; Francois, M.; Neudorf, H.; Little, J.P. Acute high-intensity interval exercise reduces human monocyte Toll-like receptor 2 expression in type 2 diabetes. Am. J. Physiol. Regul. Integr. Comp. Physiol. 2017, 312, R529-R538. [CrossRef] [PubMed]

48. Szlezak, A.M.; Szlezak, S.L.; Keane, J.; Tajouri, L.; Minahan, C. Establishing a dose-response relationship between acute resistanceexercise and the immune system: Protocol for a systematic review. Immunol. Lett. 2016, 180, 54-65. [CrossRef]

49. Dorneles, G.P.; Haddad, D.O.; Fagundes, V.O.; Vargas, B.K.; Kloecker, A.; Romão, P.R.T.; Peres, A. High intensity interval exercise decreases IL-8 and enhances the immunomodulatory cytokine interleukin-10 in lean and overweight-obese individuals. Cytokine 2016, 77, 1-9. [CrossRef]

50. Sarir, H.; Emdadifard, G.; Farhangfar, H.; TaheriChadorneshin, H. Effect of vitamin E succinate on inflammatory cytokines induced by high-intensity interval training. J. Res. Med. Sci. Off. J. Isfahan Univ. Med. Sci. 2015, 20, 1177. [CrossRef]

51. Neves, P.R.D.S.; Tenório, T.R.D.S.; Lins, T.A.; Muniz, M.T.C.; Pithon-Curi, T.C.; Botero, J.P.; Prado, W.L.D. Acute effects of highand low-intensity exercise bouts on leukocyte counts. J. Exerc. Sci. Fit. 2015, 13, 24-28. [CrossRef] [PubMed]

52. Zwetsloot, K.A.; John, C.S.; Lawrence, M.M.; Battista, R.A.; Shanely, R.A. High-intensity interval training induces a modest systemic inflammatory response in active, young men. J. Inflamm. Res. 2014, 7, 9-17. [CrossRef] [PubMed]

53. Gholamnezhad, Z.; Boskabady, M.H.; Hosseini, M.; Sankian, M.; Rad, A.K. Evaluation of immune response after moderate and overtraining exercise in wistar rat. Iran. J. Basic Med. Sci. 2014, 17, 1.

54. Zimmer, P.; Baumann, F.T.; Bloch, W.; Schenk, A.; Koliamitra, C.; Jensen, P.; Mierau, A.; Hülsdünker, T.; Reinart, N.; Hallek, M.; et al. Impact of exercise on pro inflammatory cytokine levels and epigenetic modulations of tumor-competitive lymphocytes in Non-Hodgkin-Lymphoma patients-randomized controlled trial. Eur. J. Haematol. 2014, 93, 527-532. [CrossRef] [PubMed]

55. Gałąka-Franta, A.; Jura-Szołtys, E.; Smółka, W.; Gawlik, R. Upper respiratory tract diseases in athletes in different sports disciplines. J. Hum. Kinet. 2016, 53, 99. [CrossRef] [PubMed]

56. Hull, J.H.; Loosemore, M.; Schwellnus, M. Respiratory health in athletes: Facing the COVID-19 challenge. Lancet Respir. Med. 2020, 8, 557-558. [CrossRef] 
57. Svendsen, I.S.; Taylor, I.M.; Tønnessen, E.; Bahr, R.; Gleeson, M. Training-related and competition-related risk factors for respiratory tract and gastrointestinal infections in elite cross-country skiers. Br. J. Sports Med. 2016, 50, 809-815. [CrossRef]

58. Nieman, D.C. Exercise, upper respiratory tract infection, and the immune system. Med. Sci. Sports Exerc. 1994, 26, 128-139. [CrossRef]

59. Monks, L.; Seo, M.-W.; Kim, H.-B.; Jung, H.C.; Song, J.K. High-intensity interval training and athletic performance in taekwondo athletes. J. Sports Med. Phys. Fit. 2017, 57, 1252-1260. [CrossRef]

60. Mackinnon, L.T.; Hooper, S.L. Plasma glutamine and upper respiratory tract infection during intensified training in swimmers Med. Sci. Sports. Exerc. 1996, 28, 285-290. [CrossRef]

61. Born, D.-P.; Zinner, C.; Sperlich, B. The Mucosal Immune Function Is Not Compromised during a Period of High-Intensity Interval Training. Is It Time to Reconsider an Old Assumption? Front. Physiol. 2017, 8, 485. [CrossRef]

62. Katelaris, C.H.; Carrozzi, F.M.; Burke, T.V.; Byth, K. A springtime Olympics demands special consideration for allergic athletes. J Allergy Clin. Immunol. 2000, 106, 260-266. [CrossRef]

63. Kiboneka, A.; Kibuule, D. The Immunology of Asthma and Allergic Rhinitis. In Rhinosinusitis; IntechOpen: London, UK, 2019.

64. Grimby, G. Exercise in man during pyrogen-induced fever. Scand. J. Clin. Lab. Investig. 1962, 14, 1-112.

65. Friman, G.; Wesslén, L. Infections and exercise in high-performance athletes. Immunol. Cell Biol. 2000, 78, 510-522. [CrossRef] [PubMed]

66. Suzuki, M.; Umeda, T.; Nakaji, S.; Shimoyama, T.; Mashiko, T.; Sugawara, K. Effect of incorporating low intensity exercise into the recovery period after a rugby match. Br. J. Sports Med. 2004, 38, 436-440. [CrossRef] [PubMed]

67. Beisel, W.R.; Sawyer, W.D.; Ryll, E.D.; Crozier, D. Metabolic effects of intracellular infections in man. Ann. Intern. Med. 1967, 67, 744-779. [CrossRef] [PubMed]

68. Gade, J.; Beck, A.M.; Andersen, H.E.; Christensen, B.; Rønholt, F.; Klausen, T.W.; Vinther, A.; Astrup, A. Protein supplementation combined with low-intensity resistance training in geriatric medical patients during and after hospitalisation: A randomised, double-blind, multicentre trial. Br. J. Nutr. 2019, 122, 1006-1020. [CrossRef]

69. Gärtner, B.C.; Meyer, T. Vaccination in elite athletes. Sports Med. 2014, 44, 1361-1376. [CrossRef]

70. Hull, J.H.; Wootten, M.; Ranson, C. Tolerability and impact of SARS-CoV-2 vaccination in elite athletes. Lancet Respir. Med. 2022, 10, e5-e6. [CrossRef]

71. Hekmatikar, A.H.A.; Shamsi, M.M.; Ashkazari, Z.S.Z.; Suzuki, K. Exercise in an Overweight Patient with COVID-19: A Case Study. Int. J. Environ. Res. Public Health 2021, 18, 5882. [CrossRef]

72. Andreato, L.V.; Coimbra, D.R.; Andrade, A. Challenges to athletes during the home confinement caused by the COVID-19 pandemic. Strength Cond. J. 2020, 42, 1-5. [CrossRef]

73. Nieman, D.C. Nutrition, exercise, and immune system function. Clin. Sports Med. 1999, 18, 537-548. [CrossRef]

74. Miles, M.P.; Kraemer, W.J.; Grove, D.S.; Leach, S.K.; Dohi, K.; Bush, J.A.; Marx, J.O.; Nindl, B.C.; Volek, J.S.; Mastro, A.M. Effects of resistance training on resting immune parameters in women. Eur. J. Appl. Physiol. 2002, 87, 506-508. [CrossRef] [PubMed]

75. Peake, J.; Wilson, G.; Mackinnon, L.; Coombes, J.S. Carbohydrate supplementation and alterations in neutrophils, and plasma cortisol and myoglobin concentration after intense exercise. Eur. J. Appl. Physiol. 2005, 93, 672-678. [CrossRef] [PubMed]

76. Liu, Y.; Li, D.; Chen, J.; Xie, J.; Bandyopadhyay, S.; Zhang, D.; Nemarkommula, A.R.; Liu, H.; Mehta, J.L.; Hermonat, P.L. Inhibition of atherogenesis in LDLR knockout mice by systemic delivery of adeno-associated virus type 2-hIL-10. Atherosclerosis 2006, 188, 19-27. [CrossRef] [PubMed]

77. Spruit, M.A.; Singh, S.J.; Garvey, C.; ZuWallack, R.; Nici, L.; Rochester, C.; Hill, K.; Holland, A.E.; Lareau, S.C.; Man, W.D.-C An official American Thoracic Society/European Respiratory Society statement: Key concepts and advances in pulmonary rehabilitation. Am. J. Respir. Crit. Care Med. 2013, 188, e13-e64. [CrossRef]

78. Bermon, S.; Castell, L.M.; Calder, P.C.; Bishop, N.C.; Blomstrand, E.; Mooren, F.C.; Krüger, K.; Kavazis, A.N.; Quindry, J.C.; Senchina, D.S.; et al. Consensus statement immunonutrition and exercise. Exerc. Immunol. Rev. 2017, 23, 8-50.

79. Nair, A.R.; Mariappan, N.; Stull, A.J.; Francis, J. Blueberry supplementation attenuates oxidative stress within monocytes and modulates immune cell levels in adults with metabolic syndrome: A randomized, double-blind, placebo-controlled trial. Food Funct. 2017, 8, 4118-4128. [CrossRef]

80. Lewis, E.D.; Meydani, S.N.; Wu, D. Regulatory role of vitamin E in the immune system and inflammation. IUBMB Life 2019, 71, 487-494. [CrossRef] [PubMed]

81. Gunde, M.C.; Amnerkar, N.D. Nutritional, medicinal and pharmacological properties of papaya (Carica papaya Linn.): A review. J. Innov. Pharm. Biol. Sci. 2016, 3, 162-169.

82. Meydani, S.N.; Ha, W.-K. Immunologic effects of yogurt. Am. J. Clin. Nutr. 2000, 71, 861-872. [CrossRef]

83. Talpur, A.D.; Ikhwanuddin, M.; Ambok Bolong, A.-M. Nutritional effects of ginger (Zingiber officinale Roscoe) on immune response of Asian sea bass, Lates calcarifer (Bloch) and disease resistance against Vibrio harveyi. Aquaculture 2013, 400-401, 46-52. [CrossRef]

84. Sheikhzadeh, N.; Nofouzi, K.; Delazar, A.; Oushani, A.K. Immunomodulatory effects of decaffeinated green tea (Camellia sinensis) on the immune system of rainbow trout (Oncorhynchus mykiss). Fish Shellfish Immunol. 2011, 31, 1268-1269. [CrossRef]

85. Medrano, M.; Carrillo-Cruz, E.; Montero, I.; Perez-Simon, J.A. Vitamin D: Effect on haematopoiesis and immune system and clinical applications. Int. J. Mol. Sci. 2018, 19, 2663. [CrossRef] [PubMed]

86. Saper, R.B.; Rash, R. Zinc: An essential micronutrient. Am. Fam. Physician 2009, 79, 768-772. [PubMed] 
87. Mertz, K.H.; Reitelseder, S.; Bechshoeft, R.; Bulow, J.; Højfeldt, G.; Jensen, M.; Schacht, S.R.; Lind, M.V.; Rasmussen, M.A.; Mikkelsen, U.R.; et al. The effect of daily protein supplementation, with or without resistance training for 1 year, on muscle size, strength, and function in healthy older adults: A randomized controlled trial. Am. J. Clin. Nutr. 2021, 113, 790-800. [CrossRef]

88. Chapman, S.; Chung, H.C.; Rawcliffe, A.J.; Izard, R.; Smith, L.; Roberts, J.D. Does Protein Supplementation Support Adaptations to Arduous Concurrent Exercise Training? A Systematic Review and Meta-Analysis with Military Based Applications. Nutrients 2021, 13, 1416. [CrossRef] [PubMed]

89. Kawanishi, N.; Kato, K.; Takahashi, M.; Mizokami, T.; Otsuka, Y.; Imaizumi, A.; Shiva, D.; Yano, H.; Suzuki, K. Curcumin attenuates oxidative stress following downhill running-induced muscle damage. Biochem. Biophys. Res. Communic. 2013, 441, 573-578. [CrossRef] [PubMed]

90. Ruhee, R.T.; Ma, S.; Suzuki, K. Protective effects of sulforaphane on exercise-induced organ damage via inducing antioxidant defense responses. Antioxidants 2020, 9, 136. [CrossRef] 